Annals of Plant Sciences

ISSN: 2287-688X

OPEN ACCESS

Research Article

www.annalsofplantsciences.com

\title{
Stem and leaf anatomy and achene structure in some species of Senecio (Asteraceae).
}

Büyükkartal Hatice Nurhan ${ }^{1 *}$, Hatice Çölgeçen ${ }^{2}$, Ümit Budak ${ }^{3}$

${ }^{1}$ Ankara University, Faculty of Science, Department of Biology, 06100, Tandogan, Ankara, Turkey. ${ }^{2}$ Bülent Ecevit University Faculty of Science and Arts, Department of Biology, Zonguldak, Turkey. ${ }^{3}$ Bozok University, Faculty of Science and Arts, Department of Biology, Yozgat, Turkey.

Received: 2017-10-24; Accepted: 2017-11-14

\begin{abstract}
The genus Senecio L. belongs to the tribe Senecioneae Cass. of the family Asteraceae which is the richest plant family of Turkey in terms of endemic species. The study was conducted on a total of 8 taxa belonging to Senecio. 4 taxa were collected from West and 4 were collected from East Anatolia. Stem and leaf anatomy of the taxa were studied by light microscopy; achene structure was examined by light microscopy and transmission electron microscopy in order to identify morphological, anatomical and histological modifications and resolve taxonomic problems of the genus.
\end{abstract}

Keywords: Senecio, anatomy, achene, TEM

\section{Introduction}

Asteraceae (Compositae) is the richest plant family of Turkey in terms of endemic species (Erik and Tar1kahya, 2004). The genus Senecio L. belongs to the tribe Senecioneae Cass. of the family Asteraceae (Compositae). Senecioneae is the largest tribe of the Asteraceae comprising 150 genera and 3,500 species distributed worldwide (Nordenstam, 2007) The tribe Senecioneae is represented in Turkish flora by three subtribes and a total of eight genera including subsequent additions of Ligularia Cass., Crassocephalum Moench and Adenostyles Cass. (Matthews, 1975; Kit, 2000; Akıncı and Özhatay, 2004). The newly described genera Jacobaea L. Iranecio B.Nord. and Caucasalia B.Nord. which also have taxa in Turkey are not recognized due to their taxonomic characters being insufficient and transitive. As a result of taxonomic studies, Turkish Senecio species were suggested to be transferred to the genera Senecio and Tephroseris (Rchb.) Rchb. (Hamzaoğlu et at., 2009).

The genus Senecio is represented by 102 species in Flora of the U.S.S.R, 67 species in Flora Europaea, 29 species (including Iranecio) in Flora Iranica and five species in Flora Palaestina (Shıshkın, 1995; Chater and Walters, 1976; Nordenstam, 1989; Feınbrun-Dothan, 1978). The genus is divided into sections and even series in the papers such as Flora Orientalis, Flora Europaea and Flora of the U.S.S.R. (Boissier, 1875; Chater and Walters, 1976; Shishkin, 1995). However, no sectional classification is made in Flora of Turkey (Matthews, 1975). Senecio is represented in Flora of Turkey by 52 taxa (43 species, 3 subspecies and 6 varieties). 21 of these taxa are endemic for Turkey and the rate of endemism is $40 \%$. Many morphological, anatomical (Adedeji and Jewoola, 2008; Noorbakhsh, et al., 2008; Akçin and Akçin, 2010; Garcia Breijo et al., 2011; Bona, 2014; Özbek et al., 2014; Sosa et al., 2014; Selvi et al., 2014; Karaismailoğlu, 2015; Özcan et al., 2015; Candan et al., 2016; Norouz1 et al., 2016; Ivashchenko and Ivarenko, 2017), palynological (Kandemir et al., 2006; Ghahreman et al., 2007; Quresh1 et al., 2008a,b Özmen et al., 2009; Nbagwu et al., 2009;

\section{${ }^{*}$ Corresponding Author:}

Dr. Hatice Nurhan Büyükkartal,

Ankara University,

Faculty of Science, Department of Biology, 06100,

Tandogan, Ankara, Turkey.

E-mail: bkartal7@gmail.com
Türkmen et al., 2010; Akyalcin et al., 2011; De Abreu et al., 2015), taxonomic and genetical (Karanovic et al., 2015; Hoda'Lova' et al., 2015; Andre'S-Sa'Nchez et al., 2015; Ruvimbo et al., 2016) studies have been conducted to identify relationships among Asteraceae taxa.

This study was conducted on a total of 8 taxa belonging to Senecio; 4 of which were collected from West Anatolia (Senecio jacobaea L. subsp. jacobaea, Senecio aquaticus Hill subsp. erraticus (Bertol.) V.A.Matthews, Senecio maritimus (L.) Rchb, Senecio. sandrasicus P.H.Davis) and 4 collected from East Anatolia (Senecio erucifolius L. subsp. erucifolius, Senecio grandidentatus Ledeb., Senecio mollis Willd., Senecio trapezuntinus Boiss.). Stem and leaf anatomy of the taxa were studied by light microscopy; seed coat (achene+testa) was examined by light microscopy and transmission electron microscopy (TEM) in order to identify morphological, anatomical and histological modifications and contribute to taxonomic and phlogenetic assessment of the genus.

\section{Materials and Methods}

Stem and leaf anatomy and achene histology were examined in the taxa of Senecio some species (Table 1) (Fig. 1a-h). Upper, middle and lower leaf samples and young stem samples were taken from each taxon. These were prepared for anatomical studies using paraffin method (Algan, 1981). 8-10 $\mu \mathrm{m}$ sections from leaves and $12-15 \mu \mathrm{m}$ sections from stems were taken and stained with safranin-fast green. For surface-section analyses, a sample of 20 surface-sections was taken separately from lower and upper surfaces of each of 5 randomly selected leaves per each taxon and stomatal index and stomatal index rates were calculated by the formula based on number of epidermal cells and stomata per $\mathrm{mm}^{2}$. For cross-section analyses, 5 cross-sections were taken from each of 5 randomly selected leaves per each taxon and average leaf blade thickness $(\mu \mathrm{m})$ was measured (Table 2).

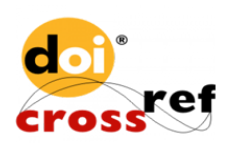


Table 1. Examined taxa of Senecio and collection localities

\begin{tabular}{|c|c|c|}
\hline Taxon Name & Collector & Collection Locality \\
\hline $\begin{array}{l}\text { Senecio jacobaea L. subsp. jacobaea } \\
\text { (S. aquaticus Hill subsp. aquaticus) }\end{array}$ & Budak- 2192 & $\begin{array}{l}\text { Kırklareli: Kırklareli-Edirne direction, 14th km, } 100 \text { m, 23.07.2007, Budak. 2192, } \\
\text { Hamzaoğlu \& Aksoy (Bozok Hb.). }\end{array}$ \\
\hline $\begin{array}{l}\text { S. aquaticus Hill subsp. erraticus } \\
\text { (Bertol.) V.A.Matthews }\end{array}$ & Budak- 2191 & $\begin{array}{l}\text { Bolu-Yedigöller direction, entrance of Yukar1 Soku village, } 740 \text { m, 22.07.2007, } \\
\text { Budak.2191, Hamzaoğlu \& Aksoy (Bozok Hb.). }\end{array}$ \\
\hline $\begin{array}{l}\text { Senecio maritimus (L.) Rchb } \\
\text { (S. bicolor (Willd.) Tod. Subsp. bicolor } \\
\text { var. bicolor) }\end{array}$ & $\begin{array}{l}\text { Hamzaoğlu- } \\
4378\end{array}$ & $\begin{array}{l}\text { Isparta: Süleyman Demirel University Campus, Faculty of Science and Arts locality, } \\
\text { 27.07.2006, Hamzaoğlu 4378, Aksoy \& Budak (Bozok Hb.). }\end{array}$ \\
\hline Senecio sandrasicus P.H.Davis & $\begin{array}{l}\text { Hamzaoğlu - } \\
4379\end{array}$ & $\begin{array}{l}\text { Muğla: Köyceğiz Yaylaköy (Ağla) village, Sandras Mountain locality, } 1545 \text { m, } \\
\text { 28.07.2006, Hamzaoğlu 4379, Aksoy \& Budak (Bozok Hb.); }\end{array}$ \\
\hline Senecio erucifolius L. subsp. erucifolius & $\begin{array}{l}\text { Hamzaoğlu- } \\
4997\end{array}$ & $\begin{array}{l}\text { Ağrı: Doğubayazıt Tendürek Passage, } 2590 \text { m, 30.07.2007, Hamzaoğlu 4997, Aksoy } \\
\text { \& Budak (Bozok Hb.). }\end{array}$ \\
\hline Senecio grandidentatus Ledeb & $\begin{array}{l}\text { Hamzaoğlu- } \\
5368\end{array}$ & $\begin{array}{l}\text { Ardahan: Posof, Yurtbekler village, } 1300 \text { m, 23.08.2008, Hamzaoğlu 5368, Budak \& } \\
\text { Aksoy (Bozok Hb.). }\end{array}$ \\
\hline Senecio mollis Willd. & Budak-2122 & $\begin{array}{l}\text { Sivas: Taşlıdere, iron-steel factory junction locality, } 1330 \text { m, 18.07.2006, Budak } \\
\text { 2122, Hamzaoğlu \& Aksoy (Bozok Hb.). }\end{array}$ \\
\hline Senecio trapezuntinus Boiss. & Budak-2011 & $\begin{array}{l}\text { Trabzon: Esentepe quarter direction, Maşatlık locality, } 120 \text { m, 21.04.2006, Budak } \\
\text { 2011, Hamzaoğlu \& Aksoy (Bozok Hb.). }\end{array}$ \\
\hline
\end{tabular}

Table 2. Mesophyll size, number of stomata per $\mathrm{mm}^{2}$, number of epidermal cells, stomatal index and stomatal index rates in Senecio taxa

\begin{tabular}{|c|c|c|c|c|c|c|}
\hline Senecio taxa & $\begin{array}{l}\text { Mesophyll } \\
\text { size }(\mu \mathrm{m})\end{array}$ & $\begin{array}{l}\text { Surface of the } \\
\text { section }\end{array}$ & $\begin{array}{l}\text { Stomata Number } \\
\left(\text { number } / \mathrm{mm}^{2}\right)\end{array}$ & $\begin{array}{c}\text { Number of } \\
\text { Epidermal Cells } \\
\left(\text { number } / \mathrm{mm}^{2}\right)\end{array}$ & $\begin{array}{l}\text { Stomatal } \\
\text { Index }\end{array}$ & $\begin{array}{c}\text { Stomatal } \\
\text { Index Rate }\end{array}$ \\
\hline \multirow[t]{2}{*}{ Senecio jacobaea L. subsp. jacobaea } & \multirow[t]{2}{*}{$266.6 \pm 6.5$} & Adaxial surface & $24.34 \pm 1.7$ & $172.96 \pm 4.0$ & $12.33 \pm 3.2$ & \multirow[t]{2}{*}{0.67} \\
\hline & & Abaxial surface & $37.15 \pm 3.8$ & $164.09 \pm 5.9$ & $18.46 \pm 1.5$ & \\
\hline \multirow{4}{*}{$\begin{array}{l}\text { S. aquaticus Hill subsp. erraticus } \\
\text { (Bertol.) V.A.Matthews } \\
\text { Senecio maritimus (L.) Rchb }\end{array}$} & \multirow[t]{2}{*}{$135.6 \pm 4.6$} & Adaxial surface & $42.2 \pm 0.2$ & $368.1 \pm 0.8$ & $10.29 \pm 0.8$ & \multirow[t]{2}{*}{0.36} \\
\hline & & Abaxial surface & $185.4 \pm 0.3$ & $463.4 \pm 0.4$ & $28.58 \pm 0.1$ & \\
\hline & \multirow[t]{2}{*}{$229.9 \pm 12.0$} & Adaxial surface & $88.1 \pm 0.6$ & $440.9 \pm 0.0$ & $16.65 \pm 0.1$ & \multirow[t]{2}{*}{0.64} \\
\hline & & Abaxial surface & $300.5 \pm 6.0$ & $851.4 \pm 1.3$ & $26.08 \pm 0.6$ & \\
\hline \multirow[t]{2}{*}{ Senecio sandrasicus P.H.Davis } & \multirow[t]{2}{*}{$246.7 \pm 4.8$} & Adaxial surface & $42.64 \pm 0.1$ & $483.2 \pm 0.2$ & $8.11 \pm 0.5$ & \multirow[t]{2}{*}{0.59} \\
\hline & & Abaxial surface & $76.0 \pm 0.0$ & $485.4 \pm 5.9$ & $13.54 \pm 0.2$ & \\
\hline \multirow[t]{2}{*}{ Senecio erucifolius L. subsp. erucifolius } & \multirow[t]{2}{*}{$135.6 \pm 4.6$} & Adaxial surface & $42.2 \pm 0.2$ & $368.1 \pm 0.8$ & $10.29 \pm 0.8$ & \multirow[t]{2}{*}{0.36} \\
\hline & & Abaxial surface & $184.4 \pm 0.3$ & $462.4 \pm 0.4$ & $26.58 \pm 0.1$ & \\
\hline \multirow[t]{2}{*}{ Senecio grandidentatus Ledeb } & \multirow[t]{2}{*}{$228.9 \pm 12.0$} & Adaxial surface & $86.1 \pm 0.6$ & $448.9 \pm 0.0$ & $16.64 \pm 0.1$ & \multirow[t]{2}{*}{0.64} \\
\hline & & Abaxial surface & $300.5 \pm 6.0$ & $851.4 \pm 1.3$ & $26.08 \pm 0.6$ & \\
\hline \multirow[t]{2}{*}{ Senecio mollis Willd. } & \multirow[t]{2}{*}{$269 \pm 7.7$} & Adaxial surface & $112.3 \pm 1.6$ & $458.3 \pm 3.1$ & $19.68 \pm 0.6$ & \multirow[t]{2}{*}{0.89} \\
\hline & & Abaxial surface & $118.8 \pm 0.0$ & $415.8 \pm 0.0$ & $22.22 \pm 0.2$ & \\
\hline \multirow[t]{2}{*}{ Senecio trapezuntinus Boiss. } & \multirow[t]{2}{*}{$111.1 \pm 6.5$} & Adaxial surface & $51.2 \pm 0.1$ & $385.2 \pm 1.0$ & $11.73 \pm 0.7$ & \multirow[t]{2}{*}{0.45} \\
\hline & & Abaxial surface & $105.5 \pm 0.0$ & $350.3 \pm 3.3$ & $26.27 \pm 0.5$ & \\
\hline
\end{tabular}

For TEM studies, achene samples per each taxon were first fixed with $3 \%$ glutaraldehyde and then with $1 \%$ osmium tetroxide. Following dehydration and saturation, samples were embedded in Epon 812 (Luft, 1961). Semi-thin sections were taken from these blocks and the sections were stained with methylene blue and toluidine blue. Ultrathin sections were first stained with uranyl acetate (Stempak and Ward, 1964) and lead citrate (Sato, 1967) then examined with Jeol CX-100 TEM.

\section{Results}

In leaf cross-sections of Senecio jacobaea L. subsp. jacobaea collected from Kirklareli-Edirne locality, two layers of cylindrical palisade parenchyma cells are observed in mesophyll tissue below upper epidermis (Fig. 2a). Sponge parenchyma cells are observed below mesophyll tissue. Leaves are bifacial. Leaf thickness is 266.6. $\pm 6.5 \mu \mathrm{m}$ (Table 2) and several layers of collenchyma cells are found in the midrib located between the upper and lower epidermis. Small bundles are collateral. The leaves are amphistomatic (Fig. 2b). Stomata are placed at the same level as the epidermal cells. In adaxial surface, amaryllis type stomata are observed in epidermal cells. The number of stomata is $24.34 \pm 1.7$ per $\mathrm{mm}^{2}$ (Table 2). Palisade parenchyma cells are oval and circular in shape (Fig.
$2 \mathrm{~b}-\mathrm{c})$. Stomata are of anomocytic type and average number of stomata in abaxial surface is $37,15 \pm 3.8$ per $\mathrm{mm}^{2}$ (Table 2). In abaxial surface, wavy-walled epidermal cells (Fig. 2d) have amaryllis type stomata (Fig. 2e). Sponge parenchyma cells have large intercellular spaces (Fig. 2f).

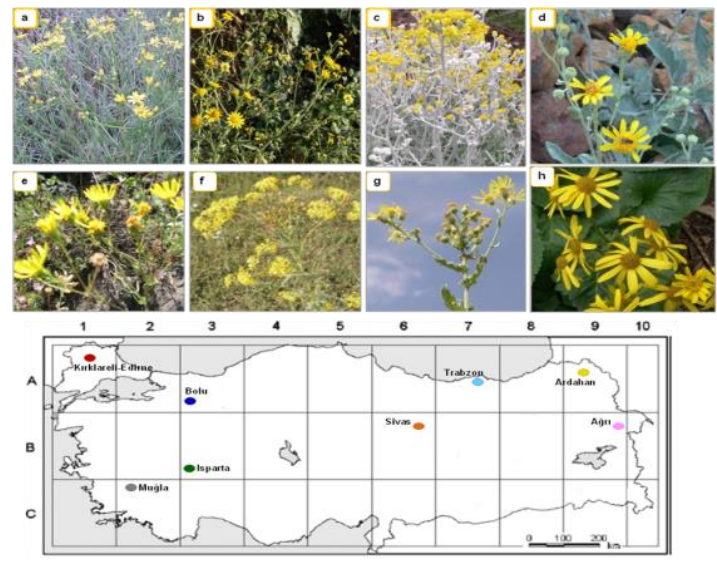

Figure 1. Habitat views and collection localities of Senecio taxa in Turkey. a. Senecio jacobaea L. subsp. jacobaea () b. Senecio aquaticus Hill subsp. erraticus (Bertol.) V.A. Matthews (-) c. Senecio maritimus (L.) Rchb (-) d. Senecio sandrasicus $(-)$ e. Senecio erucifolius L. subsp. erucifolius (○) f. Senecio grandidentatus Ledeb. (○) g. Senecio mollis Willd. (-) h. Senecio trapezuntinus Boiss. ( $)$ 


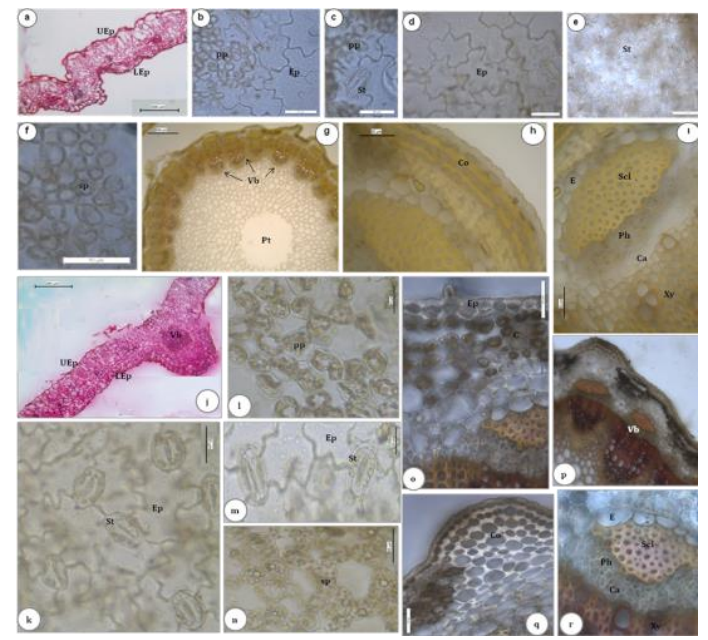

Figure 2. Leaf and stem anatomy of Senecio jacobaea L. subsp. jacobaea and Senecio aquaticus Hill subsp. erraticus (Bertol.) V.A. Matthews.

a. Leaf cross section of S. jacobaea L. subsp. jacobaea Bar $=200$ $\mu \mathrm{m}$ b. Epidermis in upper leaf surface Bar $=50 \mu \mathrm{m}$. c. Stomata in upper leaf surface Bar $=50 \mu \mathrm{m}$. d. Epidermis in lower leaf surface e. Stomata in lower leaf surface Bar $=50 \mu \mathrm{m}$. f. Sponge parenchyma in lower leaf surface Bar $=50 \mu \mathrm{m}$. g. General view of stem Bar $=500 \mu \mathrm{m} \mathrm{h}$. Collenchyma Bar $=50 \mu \mathrm{m} \mathbf{1}$. Appearence of a vascular bundle Bar $=50 \mu \mathrm{m} \mathbf{j}$. Leaf crosssection of $S$. aquaticus Hill subsp. erraticus (Bertol.) V.A. Matthews Bar $=200 \mu \mathrm{m} \mathrm{k}$. Epidermis in upper leaf surface and stomata Bar $=50 \mu \mathrm{m}$ 1. Palisade parenchyma in upper leaf surface Bar $=$ $50 \mu \mathrm{m}$. m. Epidermis and stomata in lower leaf surface Bar $=50$ $\mu \mathrm{m}$. n. Sponge parenchyma in lower leaf surface Bar $=50 \mu \mathrm{m}$. o. Chlorenchyma Bar $=50 \mu \mathrm{m}$. p. General view of stem Bar $=100$ $\mu \mathrm{m}$ q. Collenchyma Bar $=50 \mu \mathrm{m} \mathbf{r}$. Appearence of a vascular bundle $\mathrm{Bar}=50 \mu \mathrm{m}$

In stem cross-sections, vascular bundles are of open-collateral type, xylem is located towards the center of the stem and phloem is located towards the epidermis (Fig. 2g). 4-5 layers of lamellar collenchyma cells are seen below epidermis in the wavy parts of the stem (Fig. 2h). 5-7 layers of sclerenchyma bundles are observed above vascular bundles. Sclerenchyma cells are thick-walled (Fig. 21 ). The cambium is composed of 2-3 layers of thin-walled cells. Pith tissue is parenchymatic.

In leaf cross-sections of Senecio aquaticus Hill subsp. erraticus (Bertol.) V.A. Matthews collected from Bolu-Yedigöller locality, leaves are bifacial (Fig. 2j). There are glandular hairs on both leaf surfaces (Fig. $2 \mathrm{k})$. One layer of palisade parenchyma cells is observed in mesophyll tissue below upper epidermis composed by large cells. Below mesophyll tissue, there are 3-4 layers of sponge parenchyma with large intercellular spaces. 2-3 layers of collenchyma cells are found in the midrib located between the upper and lower epidermis. Small bundles are collateral. Average mesophyll size is measured as $135.6 \pm 4.6 \mu \mathrm{m}$ (Table 2). There are wavy-walled epidermal cells in abaxial and adaxial surfaces (Fig. 2l). Amaryllis type stomata are observed in surface-sections. Stomata cells are placed at the same level as the epidermal cells. Stomata neighbouring cells are of the same shape as epidermal cells and their number ranges between 3-
5. Stomata are of anomocytic type and average numbers of stomata in adaxial and abaxial surfaces are $42.2 \pm 0.2$ and $185.4 \pm 0.3$ per $\mathrm{mm}^{2}$, respectively (Table 2). In adaxial surface, palisade parenchyma cells are oval and circular in shape (Fig. $2 \mathrm{~m})$. In abaxial surface, amaryllis type stomata are observed in epidermal cells. (Fig. 2n). Sponge parenchyma cells have large intercellular spaces (Fig. 2o).

The stem is surrounded by a single layer of epidermis with a thick cuticle at the outermost layer (Fig. 2p). 2-3 layers of lamellar collenchyma are seen below epidermis concomitant with a significant decrease in wall thickness at the corner where they connect with the cortex (Fig. 2q). Parenchymatic cells with abundant chloroplast (Chlorenchyma) exist just below epidermis around large vascular bundles (Fig. 2r). Large groups of phloem sclerenchyma bundles are located between cortex parenchyma and phloem. 2-3 layers of vascular cambium are located below phloem (Fig. $2 \mathrm{r})$.

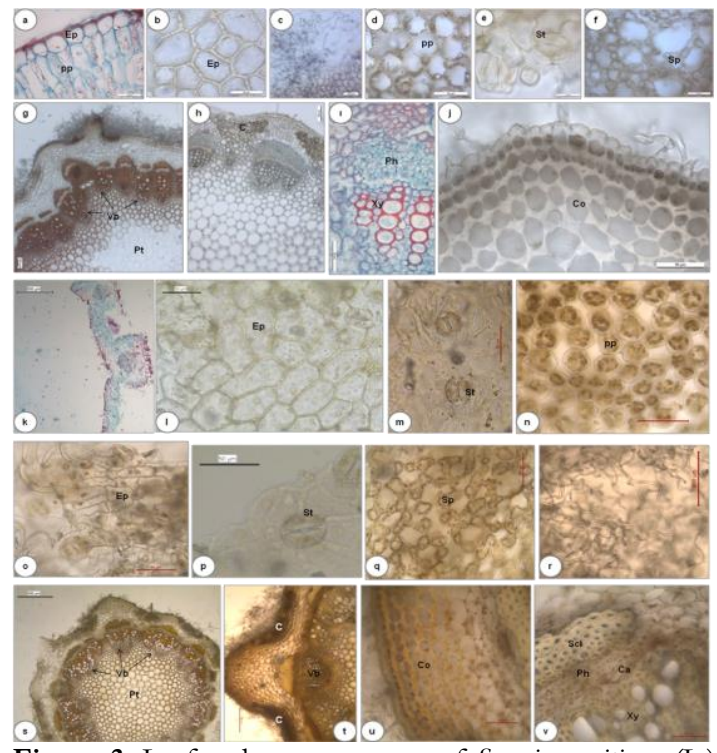

Figure 3. Leaf and stem anatomy of Senecio maritimus (L.) Rchb (Senecio bicolor (Willd.) Tod. ssp. bicolor var. bicolor) and Senecio sandrasicus P.H.Davis

a. Palisade parenchyma in leaf of S. maritimus (L.) Rchb Bar $=50$ $\mu \mathrm{m}$ b. Epidermis in upper leaf surface Bar $=50 \mu \mathrm{m}$. c. Cover hairs in upper leaf surface Bar $=100 \mu \mathrm{m}$. d. Palisade parenchyma in upper leaf surface Bar $=50 \mu \mathrm{m}$. e. Epidermis and stomata in lower leaf surface Bar $=50 \mu \mathrm{m}$. f. Sponge parenchyma in lower leaf surface Bar $=50 \mu \mathrm{m}$. g. General view of stem Bar $=100 \mu \mathrm{m}$ h. Chlorenchyma Bar $=100 \mu \mathrm{m}$ 1. Appearence of a vascular bundle Bar $=50 \mu \mathrm{m}$ j. Collenchyma Bar $=50 \mu \mathrm{m}$. k. General view of leaf cross-section of S. sandrasicus P.H.Davis Bar $=500$ $\mu \mathrm{m}$. 1. Epidermis in upper leaf surface Bar $=50 \mu \mathrm{m}$. m. Stomata in upper leaf surface Bar $=50 \mu \mathrm{m}$. $\mathbf{n}$. Palisade parenchyma in upper leaf surface Bar $=50 \mu \mathrm{m}$. o. Epidermis and cover hairs in lower leaf surface Bar $=50 \mu \mathrm{m}$. p. Epidermis and stomata in lower leaf surface Bar $=50 \mu \mathrm{m}$. q. Sponge parenchyma in lower leaf surface Bar $=50 \mu \mathrm{m}$. r. Cover hairs in lower leaf surface Bar $=50 \mu \mathrm{m}$. s. General view of stem Bar $=500 \mu \mathrm{m} . \mathbf{t}$. Chlorenchyma Bar $=200 \mu \mathrm{m}$. u. Collenchyma Bar $=50 \mu \mathrm{m}$. v. Appearence of a vascular bundle Bar $=50 \mu \mathrm{m}$. 
In leaf cross-sections of Senecio maritimus (L.) Rchb collected from Isparta: Süleyman Demirel University Campus, Faculty of Science and Arts locality, 2-3 layers of cylindrical palisade parenchyma cells are observed in mesophyll tissue below upper epidermis (Fig. 3a). Below mesophyll tissue is sponge parenchyma. Leaves are bifacial. Leaf thickness (average mesophyll size) is $229.9 \pm 12.0 \mu \mathrm{m}$ (Table 2) and several layers of collenchyma cells are found in the midrib located between the upper and lower epidermis. Arcshaped sclerenchyma bundles are seen around vascular bundles. Small bundles are of collateral type. The leaves are amphistomatic. Stomata are placed at the same level as the epidermal cells. Stomata are of anomocytic type and average numbers of stomata in adaxial and abaxial surfaces are $88.1 \pm 0.6$ and $300.5 \pm 6.0$ per $\mathrm{mm}^{2}$, respectively (Table 2). In adaxial surface, amaryllis type stomata and abundant glandular hairs are observed in polygonal-shaped epidermal cells (Figs. 3b-c). Palisade parenchyma cells are oval and circular in shape. Chloroplasts are abundant and aligned along the cell wall (Fig. 3d). Amaryllis type stomata are observed in abaxial surface (Fig. 3e). Sponge parenchyma cells have large intercellular spaces (Fig. 3f).

In stem cross-sections, vascular bundles are of open-collateral type (Fig. 3g). The number of vascular bundles in stem primary structure ranges between 20-24. 5-7 layers of sclerenchyma bundles are seen above vascular bundles. Sclerenchyma cells have thick walls (Fig. 3h). The cambium is composed of 1-2 layers of thin-walled cells. Trachea in xylem are formed from a row of cylindrical cells arranged in radial series (Fig. 31). 4-5 layers of lamellar collenchyma cells are seen below epidermis (Fig. 3j). Angular collenchyma cells exist in some parts. Like the leaf cross-sections, stem cross-sections have cover and glandular hairs. The head of glandular hairs has about 2-3 and the stalk has about 2-7 cells. Pith tissue is comprised of parenchymatic cells.

In leaf cross-sections of Senecio sandrasicus P.H.Davis collected from Muğla: Köyceğiz Yayla (Ağla) village, Sandras Mountain locality, leaves are bifacial. There are glandular hairs on both leaf surfaces. 1-2 layers of palisade parenchyma cells are observed in mesophyll tissue below upper epidermis. Sponge parenchyma cells with large intercellular spaces are seen below mesophyll tissue. 2-3 layers of collenchyma cells are found in the midrib located between the upper and lower epidermis. Small bundles are collateral (Fig. 3k). Average mesophyll size is measured as $246.7 \pm 4.8$ $\mu \mathrm{m}$ (Table 2).

Epidermal cells in lower and upper leaf sections have flat walls perforated by simple pits (Fig. 31). Amaryllis type stomata are observed in surface- sections (Fig. 3m). Stomata are placed at the same level as the epidermal cells. Stomata neighbouring cells are of the same shape as epidermal cells and their number ranges between 3-5. Stomata are of anomocytic type and average numbers of stomata in adaxial and abaxial surfaces are $42.64 \pm 0.1$ and $76.0 \pm 0.0$ per $\mathrm{mm}^{2}$, respectively (Table 2 ). Palisade parenchyma cells are oval and contain chloroplasts (Fig. 3n). Average numbers of epidermal cells in adaxial and abaxial surfaces are 483.2 \pm 0.2 and 485.4 \pm 5.9 per $\mathrm{mm}^{2}$, respectively (Table 2 ). Lower leaf surface has stomata and leaves are amphistomatic (Figs. 3o-p). Sponge parenchyma cells have large intercellular spaces (Fig. 3q). Lower leaf surface has plenty of cover hairs (Fig. 3r).

The stem is surrounded by a single layer of epidermis with a thick cuticle at the outermost layer (Fig. 3s). Parenchymatic cells with abundant chloroplast (Chlorenchyma) exist just below epidermis around large vascular bundles. The stem has abundant cover and glandular hairs (Fig. 3t). 23 layers of lamellar collenchyma cells are seen below epidermis (Fig. 3u). In stem cross-sections, vascular bundles are of open-collateral type (Fig. $3 \mathrm{v}$ ). Large groups of phloem sclerenchyma bundles are located between cortex parenchyma and phloem. 2-3 layers of vascular cambium are located below phloem. An internal gland with apparent intercellular spaces exists just above the phloem sclerenchyma. The layer just above vascular bundles separating the outer cortex from the central cylinder is endodermis.

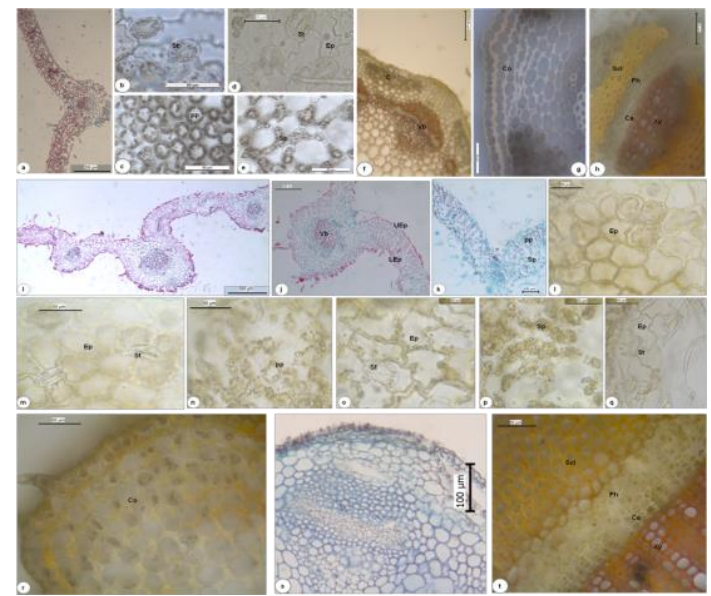

Figure 4. Leaf and stem anatomy of Senecio erucifolius L. subsp. erucifolius and Senecio grandidentatus Ledeb.

a. Main rib in leaf cross-section of S. erucifolius L. subsp. erucifolius Bar $=200 \mu \mathrm{m}$. b. Epidermis and stomata in upper leaf surface Bar $=50 \mu \mathrm{m}$. c. Palisade parenchyma in upper leaf surface Bar $=$ $50 \mu \mathrm{m}$. d. Epidermis and stomata in lower leaf surface Bar $=50$ $\mu \mathrm{m}$. e. Sponge parenchyma in lower leaf surface Bar $=50 \mu \mathrm{m}$. $\mathbf{f}$. General view of stem Bar $=200 \mu \mathrm{m}$. g. Collenchyma Bar $=50$ $\mu \mathrm{m}$. h. Appearence of a vascular bundle Bar $=50 \mu \mathrm{m}$. $\mathbf{1 - j}$. General view of leaf cross-section and midrib l-Bar $=500 \mu \mathrm{m}, \mathrm{j}-$ Bar $=200 \mu \mathrm{m}$. k. Mesophyll tissue in leaf cross-section of $S$. grandidentatus Ledeb. Bar $=50 \mu \mathrm{m}$. 1. Epidermis in upper leaf surface Bar $=50 \mu \mathrm{m} . \mathbf{m}$. Stomata in upper leaf surface Bar $=50$ $\mu \mathrm{m}$. n. Palisade parenchyma in upper leaf surface Bar $=50 \mu \mathrm{m}$. o. Epidermis and stomata in lower leaf surface Bar $=50 \mu \mathrm{m}$. p. Sponge parenchyma in lower leaf surface Bar $=50 \mu \mathrm{m}$. q. Cover 
hairs in lower leaf surface Bar $=50 \mu \mathrm{m}$. $\mathbf{r}$. Collenchyma in stem Bar $=500 \mu \mathrm{m}$. s-t. Appearence of a vascular bundle s-Bar $=100$ $\mu \mathrm{m}, \mathrm{t}-\mathrm{Bar}=50 \mu \mathrm{m}$.

In leaf cross-sections of Senecio erucifolius L. subsp. erucifolius collected from Ağr1: Doğubayazıt Tendürek Passage, leaves are bifacial (Fig. 4a). One layer of palisade parenchyma cells is observed in mesophyll tissue below upper epidermis. Below mesophyll tissue, there are 3-4 layers of sponge parenchyma with large intercellular spaces. 2-3 layers of collenchyma cells are aligned in the midrib located between the upper and lower epidermis. Small bundles are collateral. Epidermal cells in abaxial and adaxial sections have wavy walls perforated by simple pits. Amaryllis type stomata are observed in surface-sections (Fig. 4b). Stomata are placed at the same level as the epidermal cells. Stomata are of anomocytic type and average numbers of stomata in adaxial and abaxial surfaces are $42.2 \pm 0.2$ and $184.4 \pm 0.3$ per $\mathrm{mm}^{2}$, respectively. Average numbers of epidermal cells in adaxial and abaxial surfaces are $368.1 \pm 0.8$ and $462.4 \pm 0.4$ per $\mathrm{mm}^{2}$, respectively. In upper leaf surface, palisade parenchyma cells are oval and circular in shape (Fig. 4c). Lower leaf surface has stomata and leaves are amphistomatic (Fig. 4d). Sponge parenchyma cells have large intercellular spaces (Fig. 4e). Average mesophyll size is $135.6 \pm 4.6 \mu \mathrm{m}$ (Table 2).

The stem is surrounded by a single layer of epidermis with a thick cuticle at the outermost layer (Fig. 4f). Parenchymatic cells with abundant chloroplast (Chlorenchyma) exist just below epidermis around large vascular bundles (Fig. 4f). 23 layers of lamellar collenchyma are seen below epidermis concomitant with a significant decrease in wall thickness at the corner where they connect with the cortex (Fig. 4g). In stem cross-sections, vascular bundles are of open-collateral type (Fig. 4h). Large groups of phloem sclerenchyma bundles are present between cortex parenchyma and phloem. 2-3 layers of vascular cambium are located below phloem.

In leaf cross-sections of Senecio grandidentatus Ledeb. collected from Ardahan: Posof, Yurtbekler Village, leaves are bifacial (Fig. 41). One layer of palisade parenchyma cells is observed in mesophyll tissue below upper epidermis composed by large cells. Below mesophyll tissue, there are 2-3 layers of sponge parenchyma with large intercellular spaces. 2-3 layers of collenchyma cells are located in the midrib located between the upper and lower epidermis. Vascular bundles are of collateral type (Figs. 4j, k). Average mesophyll size is measured as $228.9 \pm 12.0 \mu \mathrm{m}$ (Table 2). Rectangular, pentagonal, hexagonal epidermal cells in lower and upper leaf sections have flat walls perforated by simple pits (Figs. 4l, m). Amaryllis type stomata are observed in surface-sections (Figs. 4n, o). Stomata are placed at the same level as the epidermal cells. Stomata are of anomocytic type and average numbers of stomata in adaxial and abaxial surfaces are 86.1 \pm 0.6 and $300.5 \pm 6.0$ per $\mathrm{mm}^{2}$, respectively. Lower leaf surface has stomata and leaves are amphistomatic. Average numbers of epidermal cells in adaxial and abaxial surfaces are $448.9 \pm 0.0$ and $851.4 \pm 1.3$ per $\mathrm{mm}^{2}$, respectively. In upper leaf surface, palisade parenchyma cells are oval and circular in shape (Fig. $4 \mathrm{p}$ ). Sponge parenchyma cells have large intercellular spaces and contain less amount of chloroplast compared to that of palisade cells (Fig. $4 q)$.

The stem is surrounded by a single layer of epidermis with a thick cuticle at the outermost layer. There are large vascular bundles that bulge outward. 2-3 layers of lamellar collenchyma are seen below epidermis concomitant with a significant decrease in wall thickness at the corner where they connect with the cortex (Fig. 4r). Parenchymatic cells with abundant chloroplast (Chlorenchyma) exist just below epidermis around large vascular bundles. In stem cross-sections, vascular bundles are of open-collateral type (Figs. $4 \mathrm{~s}, \mathrm{t})$. Large groups of phloem sclerenchyma bundles are present between cortex parenchyma and phloem. 2-3 layers of vascular cambium are located below phloem.

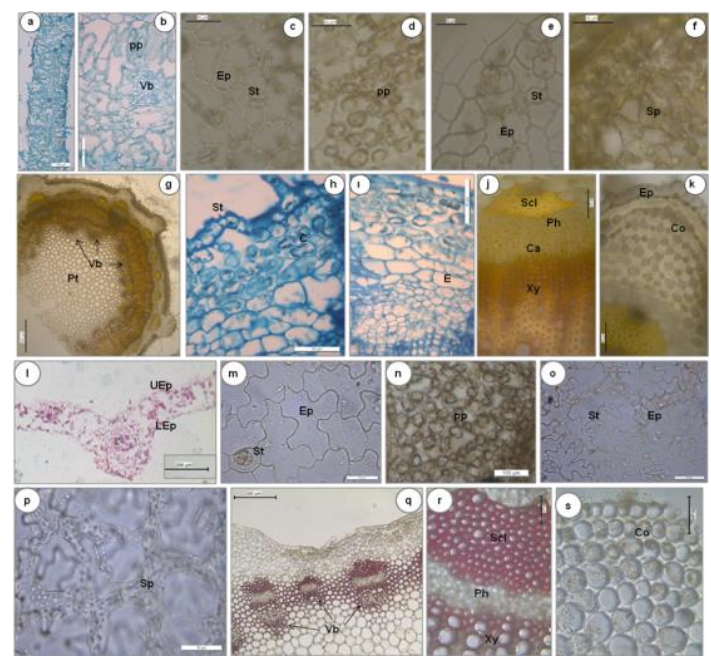

Figure 5. Leaf and stem anatomy of Senecio mollis Willd. and Senecio trapezuntinus Boiss.

a. Leaf cross-section of $S$. mollis Willd. Bar $=200 \mu \mathrm{m}$. b. Mesophyll in leaf cross $\mathrm{Bar}=200 \mu \mathrm{m}$. c. Epidermis and stomata in upper leaf surface Bar $=50 \mu \mathrm{m}$. d. Palisade parenchyma in upper leaf surface Bar $=50 \mu \mathrm{m}$. e. Epidermis and stomata in lower leaf surface Bar $=50 \mu \mathrm{m}$. f. Sponge parenchyma in lower leaf surface Bar $=50 \mu \mathrm{m}$. g. General view of stem Bar $=200$ $\mu \mathrm{m}$. h. Chlorenchyma Bar $=50 \mu \mathrm{m}$. 1. Endodermis Bar $=50 \mu \mathrm{m}$. j. Appearence of a vascular bundle Bar $=50 \mu \mathrm{m}$. k. Collenchyma $\mathrm{Bar}=50 \mu \mathrm{m}$. 1. Leaf cross-section and main rib of $S$. trapezuntinus Boiss. Bar $=200 \mu \mathrm{m}$. m. Epidermis and stomata in upper leaf surface $\mathrm{Bar}=50 \mu \mathrm{m}$. n. Palisade parenchyma in upper leaf surface Bar $=100 \mu \mathrm{m}$. o. Epidermis and stomata in lower leaf surface $B a r=50 \mu \mathrm{m}$. p. Sponge parenchyma in lower leaf surface $B a r=50 \mu \mathrm{m}$. q. General view of stem Bar $=200 \mu \mathrm{m}$. $\mathbf{r}$. Vascular bundle in stem Bar $=50 \mu \mathrm{m}$. s. Collenchyma Bar $=50$ $\mu \mathrm{m}$ 
Abbreviations : C: Chlorenchyma, Ca: Cambium, Co: Collencyhma, E: Endodermis, Ep: Epidermis, Gh: Glandular hair, LEp: Lower epidermis, Ph: Phloem, pp: Palisade parencyhma, Pt: Pith tissue, Sd: Secretory duct, Scl: Sclerenchyma, sp: Sponge parenchyma, St: Stomata, UEp: Upper epidermis, Vb: Vascular bundle, Xy: Xylem.

In leaf cross-sections of Senecio mollis Willd. collected from Sivas: Taşlıdere, iron-steel factory junction locality, leaves are bifacial. There are glandular hairs on both leaf surfaces. 1-2 layers of palisade parenchyma cells are observed in mesophyll tissue below upper epidermis composed by large cells. Below mesophyll tissue, there are 2-3 layers of sponge parenchyma with large intercellular spaces. 2-3 layers of collenchyma cells are arranged in the midrib located between the upper and lower epidermis. Small bundles are collateral (Fig. 5a-b). Epidermal cells in upper leaf section have wavy walls perforated by simple pits (Figure 5c). Amaryllis type stomata are observed in surfacesections. Stomata are placed at the same level as the epidermal cells. Stomata neighbouring cells are of the same shape as epidermal cells and their number ranges between 3-5. Stomata are of anomocytic type and average numbers of stomata in adaxial and abaxial surfaces are $112.3 \pm 1.6$ and $118.8 \pm 0.0$ per $\mathrm{mm}^{2}$, respectively. Lower leaf surface has stomata and leaves are amphistomatic. Average numbers of epidermal cells in adaxial and abaxial surfaces are $458.3 \pm 3.1$ and $415.8 \pm 0.0$ per $\mathrm{mm}^{2}$, respectively. In upper leaf surface, palisade parenchyma cells are oval and circular in shape (Fig. 5d). In lower leaf surface are wavy-walled epidermal cells (Fig. 5e). Sponge parenchyma cells have large intercellular spaces (Fig. 5f). Average mesophyll size is $269 \pm 7.7$ $\mu \mathrm{m}$ (Table 2).

The stem is surrounded by a single layer of epidermis with a thick cuticle at the outermost layer (Fig. 5g). Parenchymatic cells with abundant chloroplast (Chlorenchyma) exist just below epidermis around large vascular bundles (Fig. 5h). In stem cross-sections, vascular bundles are of open-collateral type (Figs. 51-j), xylem is located towards the center of the stem and phloem is located towards the epidermis. Large groups of phloem sclerenchyma bundles are located between cortex parenchyma and phloem. 2-3 layers of vascular cambium are located below phloem. The stem has abundant glandular hairs. An internal gland with apparent intercellular spaces exists just above the phloem sclerenchyma. The layer just above vascular bundles separating the outer cortex from the central cylinder is endodermis. In some samples, secondary thickening is observed in stem. Around large vascular bundles, 2-3 layers of lamellar collenchyma are seen below epidermis concomitant with a significant decrease in wall thickness at the corner where they connect with the cortex (Fig. 5k).
In leaf cross-sections of Senecio trapezuntinus Boiss. collected from $60 \mathrm{~m}$ east of Trabzon: Boztepe transmitters, leaves are bifacial (Fig. 51). One layer of palisade parenchyma cells is observed in mesophyll tissue below upper epidermis composed by large cells. Below mesophyll tissue, there are 3-4 layers of sponge parenchyma with large intercellular spaces. 2-3 layers of collenchyma cells are located in the midrib located between the upper and lower epidermis. Small bundles are collateral. Epidermal cells in upper leaf section have wavy walls perforated by simple pits (Fig. 5m). In upper leaf surface, palisade parenchyma cells are oval and circular in shape (Fig. 5n). Chloroplasts are abundant and aligned along the cell wall. Amaryllis type stomata are observed in surface-sections (Figs. 5m, o). Stomata are placed at the same level as the epidermal cells. Stomata neighbouring cells are of the same shape as epidermal cells and their number ranges between 35. Stomata are of anomocytic type and average numbers of stomata in adaxial and abaxial surfaces are $51.2 \pm 0.1$ and $105.5 \pm 0.0$ per $\mathrm{mm}^{2}$, respectively. Lower leaf surface has stomata and leaves are amphistomatic. Average numbers of epidermal cells in adaxial and abaxial surfaces are 385.2 \pm 1.0 and $350.3 \pm 3.3$ per $\mathrm{mm}^{2}$, respectively. Sponge parenchyma cells have large intercellular spaces (Fig. 5p). Average mesophyll size is $111.1 \pm 6.5 \mu \mathrm{m}$ (Table 2).

The stem is surrounded by a single layer of epidermis with a thick cuticle at the outermost layer. Parenchymatic cells with abundant chloroplast (Chlorenchyma) exist just below epidermis around large vascular bundles (Fig. 5q). In stem cross-sections, vascular bundles are of open-collateral type (Fig. 5r) Large groups of phloem sclerenchyma bundles are located between cortex parenchyma and phloem. 2-3 layers of vascular cambium are located below phloem. An internal gland with apparent intercellular spaces exists just above the phloem sclerenchyma. The layer just above vascular bundles separating the outer cortex from the central cylinder is endodermis. 2-3 layers of lamellar collenchyma are present below epidermis (Fig. 5s).

In achene fruit of $S$. jacobaea L. subsp. jacobaea, the cuticle above epidermal cells is thick and darkstained (Figs. 6a-b). Below epidermis are 3-4 layers of sclerenchyma bundles among thin-walled cells (Fig. 6c). Sclerenchyma cells are thick-walled and electron-opaque (Fig. 6d). Mid-layer cells have wavy and thick walls and tannin is detected in some of the cells (Fig. 6e). Achene of S. aquaticus Hill ssp. erraticus (Bertol.) V:A. Mathews. (Senecio erraticus Bertol.) is circular (Fig. 6f). Epidermal cells are long and wavy-walled. The cuticle is dark stained. Below epidermis are 3-4 layers of thick-walled sclerenchyma cells (Figs. 6g-h). Below sclerenchyma cells are mid-layer cells, some having 
prismatic crystals (Fig. 61). In electron microscopy images, a thick cuticle was detected above epidermal cells (Fig. 6j). Sclerenchyma cells have thick and electron-opaque walls (Fig. 6k). Prismatic crystals are seen in mid-layer cells (Fig. 6l).

In achene fruit of $S$. maritimus (L.) Rchb., there is a thin cuticle above epidermal cells (Fig. 6m). Below epidermis are 5-6 layers of sclerenchyma cells (Fig. 6n). Below sclerenchyma cells, there are 3-5 layers of thin-walled mid-layer cells. Ultrathin sections show that sclerenchyma cells have thick walls and lumens are full in some of the cells (Fig. 6o). The walls of sclerenchyma cells are electron-transparent. Mid-layer cells are thick-walled (Fig. 6p).

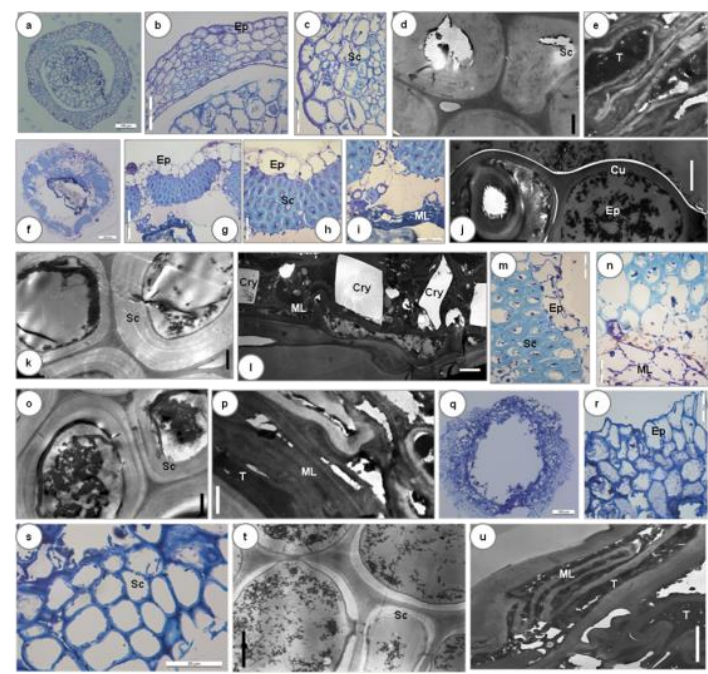

Figure 6a. General view of achene fruit structure of $S$. jacobaea L. subsp. Jacobaea Bar $=100 \mu \mathrm{m}$. b. Epidermal cells $\mathrm{Bar}=50 \mu \mathrm{m}$. c. Sclerenchyma cells Bar $=20 \mu \mathrm{m}$. d. Electron micrograph of sclerenchyma cells Bar $=2$ $\mu \mathrm{m}$. e. Mid-layer cells in achene fruit Bar $=1 \mu \mathrm{m}$. $\mathbf{f}$. General view of achene fruit structure of $S$. aquaticus Hill ssp. erraticus (Bertol.) V:A. Mathews. Bar $=100 \mu \mathrm{m}$. g. Epidermal cells Bar $=50 \mu \mathrm{m}$. h. Sclerenchyma bundle Bar $=20 \mu \mathrm{m}$. 1. Mid-layer Bar $=20 \mu \mathrm{m}$ j. Electron micrograph of epidermal cells Bar $=5 \mu \mathrm{m} . \mathbf{k}$. Sclerenchyma cells Bar $=3 \mu \mathrm{m}$. 1. Crystals in mid-layer cells Bar $=3 \mu \mathrm{m}$. m-n Epidermis and sclerenchyma cells in achene fruit of $S$. maritimus (L.) Rchb Bars $=20 \mu \mathrm{m}$. o. Electron micrograph of sclerenchyma cells $\mathrm{Bar}=2$ $\mu \mathrm{m}$. p. Electron micrograph of mid-layer cells Bar $=2$ $\mu \mathrm{m}$. q. General view of achene fruit structure of $S$. sandrasicus P.H.Davis Bar $=100 \mu \mathrm{m}$. r. Epidermal cells Bar $=20 \mu \mathrm{m}$. s. Sclerenchyma cells in achene fruit Bar $=$ $20 \mu \mathrm{m}$. t. Electron micrograph of sclerenchyma cells Bar $=5 \mu \mathrm{m}$. u. Electron micrograph of mid-layer cells Bar $=$ $3 \mu \mathrm{m}$.

Achene fruit of S. sandrasicus P.H.Davis has a thinwalled cuticle above epidermal cells (Figs. 6q-r). Below epidermis are 3-5 layers of thick-walled sclerenchyma cells (Fig. 6s). Lumens of sclerenchyma cells are wide (Fig. 6t). Wavy-walled, dark-stained mid-layer cells are observed below sclerenchyma cells (Fig. 6u)
In achene fruit of S. erucifolius L. subsp. erucifolius, epidermis consists of long, oval-shaped cells (Fig. 7a). Small sclerenchyma bundles are detected in dark-stained mid-layer cells (Fig. 7b). In achene electron micrographs, epidermal cells have vacuoles (Fig. 7c). The walls of mid-layer cells are wavy, considerably thick and some are electron-dense (Fig. 7d).

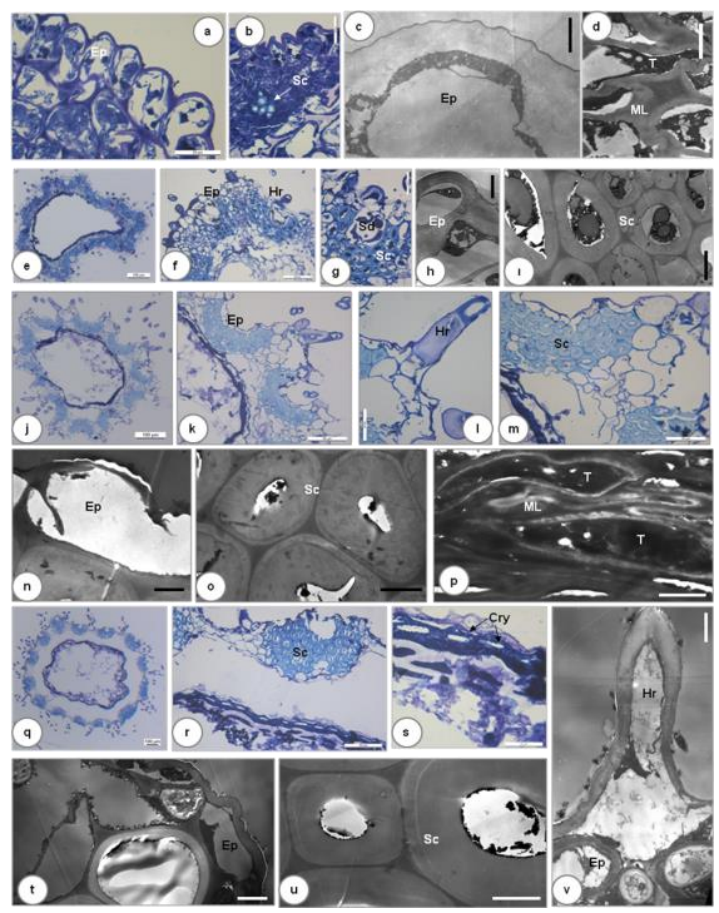

Figure 7a. Epidermal cells in achene fruit of S. erucifolius L. subsp. erucifolius $\mathrm{Bar}=20 \mu \mathrm{m}$. b. Small sclerenchyma bundles in mid-layer cells (arrow). Bar $=20 \mu \mathrm{m}$. c. Electron micrograph of epidermal cells Bar $=3 \mu \mathrm{m}$. d. Electron micrograph of mid-layer cells. Bar $=3 \mu \mathrm{m}$. e. General view of achene fruit structure of $S$. grandidentatus Ledeb. Bar $=100 \mu \mathrm{m}$. f. Epidermal cells and hairs Bar $=$ $50 \mu \mathrm{m}$. g. Secretory duct in sclerenchyma bundle Bar $=$ $20 \mu \mathrm{m}$. h. Electron micrograph of epidermal cells Bar $=5$ $\mu \mathrm{m}$. 1. Electron micrograph of sclerenchyma cells $\mathrm{Bar}=5$ $\mu \mathrm{m}$. j. General view of achene fruit structure of $S$. mollis Willd. Bar $=100 \mu \mathrm{m}$. k. Epidermal cells Bar $=50 \mu \mathrm{m}$. 1 . Hair in achene fruit Bar $=20 \mu \mathrm{m}$. m. Sclerenchyma bundle $B a r=20 \mu \mathrm{m}$. n. Electron micrograph of epidermal cells Bar $=3 \mu \mathrm{m}$. o. Electron micrograph of sclerenchyma cells Bar $=3 \mu \mathrm{m}$. p. Electron micrograph of mid-layer cells. Bar $=2 \mu \mathrm{m}$. q. General view of achene fruit structure of S. trapezuntinus Boiss. Bar $=100 \mu \mathrm{m}$. $\mathbf{r}$. Sclerenchyma bundles Bar $=50 \mu \mathrm{m}$. s. Crystals in midlayer cells (arrows). Bar $=20 \mu \mathrm{m}$. t. Electron micrograph of epidermal cells Bar $=5 \mu \mathrm{m}$. $\mathbf{u}$. Electron micrograph of sclerenchyma cells Bar $=3 \mu \mathrm{m}$. v. Hair Bar $=3 \mu \mathrm{m}$.

Abbreviations: Cry: Crystal, $\mathrm{Cu}$ : Cuticula, Ep: Epidermis, Hr: Hair, ML: Mid-layer cells, Sd: Secretory duct, Sc: Sclerenchyma, T: tanin.

In achene fruit of $S$. grandidentatus Ledeb., short hairs are seen partly in epidermal cells (Figs. 7e-f). Below epidermis are 3-5 layers of sclerenchyma cells with dark-stained and thickened walls. Secretory ducts were observed partly along the achene wall (Fig. 7g). In achene electron 
micrographs, epidermal cells have vacuoles (Fig. 7h). Lumens of sclerenchyma cells are full (Fig. 71).

Achene fruit of $S$. mollis Willd. has a dark-stained cuticle above epidermal cells (Fig. 7j). Below epidermis are 3-5 layers of thick-walled sclerenchyma cells (Fig. 7k). Epidermis has cover hairs (Fig. 7l). Dark-stained mid-layer cells are observed below sclerenchyma cells (Fig. 7m).

In electron microscopy images, epidermal cells are long, oval-shaped and the cuticle is dark-stained (Fig. 7n). Sclerenchyma cells have narrow lumens (Fig. 7o). Wavy-walled, dark-stained mid-layer cells are detected below sclerenchyma cells (Fig. 7p). Some cells have tannin.

Achene fruit of S. trapezuntinus Boiss. is oval-shaped (Fig. 7q). In wavy parts of the fruit, epidermal cells develop indents from the outside inward. Below epidermis, there are partly seen 4-5 layers of sclerenchyma bundles (Fig. 7r). Below sclerenchyma bundles are wavy-walled mid-layer cells some of which have prismatic crystals (Fig. $7 \mathrm{~s}$ ). Short hairs comprised of epidermal cells are thick-walled (Fig. 7t). Epidermal cells are long, rectangular-shaped and have thick cuticles (Fig. $7 \mathrm{u}$ ). Sclerenchyma cells have thick walls (Fig. 7v).

\section{Discussion}

This study was conducted on a total of 8 taxa belonging to Senecio; 4 of which were collected from West Anatolia (S. jacobaea L. subsp. jacobaea, S. aquaticus Hill subsp. erraticus (Bertol.) V.A.Matthews, S. maritimus (L.) Rchb, S. sandrasicus P.H.Davis) and 4 collected from East Anatolia (S. erucifolius L. subsp. erucifolius, S. grandidentatus Ledeb., S.mollis Willd., S. trapezuntinus Boiss.). Leaf and stem anatomy and achene histology of the taxa were studied in order to identify similarities and differences among examined species.

Leaf anatomy among species was not significantly different. The leaves of the examined species are amphistomatic. In species of section Jacobeae, stomata are amaryllis type and anomocytic as indicated by neighbouring cells. Leaves are bifacial. Walls of epidermal cells on leaf upper and lower surfaces are slightly wavy in species of S. jacobaea L. subsp. Jacobaea, S. aquaticus Hill subsp. erraticus (Bertol.) V.A.Matthews, S. erucifolius L. subsp. erucifolius and $S$. trapezuntinus Boiss.and are polygonal in species of $S$. maritimus (L.) Rchb, S. sandrasicus P.H. Davis and S. mollis Willd. The highest leaf thickness was measured in species of $S$. mollis Willd. and the smallest leaf thickness was measured in species of S. aquaticus Hill subsp. erraticus (Bertol.) V.A.Matthews and S. erucifolius L. subsp. erucifolius (Table 2).
As a result, while there are differences among 8 species of Senecio in mesophyll thickness and numbers of epidermal cells and stomata, the shapes and structures of these cells are similar.

Metcalfe and Chalk (1950) reported that species of Asteraceae (Compositae) exhibit differences as regards stomata distribution on leaf surface, positions of guard cell and epidermal cells, hypoderm development on leaf upper surface, mesophyll and vascular system and waxy coating on leaves

The anatomical features that can be observed in Asteraceae family are: presence of various types of glandular or covering trichomes; papillae on epidermis; anomocytic, anisocytic and rarely heliocytic stomata; presence of hypoderm; homogeneous or heterogeneous mesophyll; and vascular bundles with parenchymatic sheath composed by large cells (Metcalfe and Chalk, 1979).

In the stem cross-sections of all 8-species studied, epidermis consists of a single row of cells. In young stems, stomata are detected in epidermis. In species of S. maritimus (L.) Rchb., S. sandrasicus P.H.Davis and $S$. mollis Willd., the stem has more abundant glandular and cover hairs compared to those of other studies species. Multiple layers of lamellar collenchyma cells are seen below epidermis and changes are observed in cell walls as the collenchyma approaches vascular bundles. The cortex is parenchymatic. In the stem cortex, below collencyhma are thin-walled parenchyma cells. Vascular bundles are of open-collateral type. The cambium is composed of multiple layers of thinwalled cells.

In achene fruit of species S. erucifolius L. subsp. erucifolius and $S$. jacobaea L. subsp. Jacobaea, sclerenchyma cells are in the form of small bundles, whereas in other species, they occur as strongly developed structures. In species $S$. grandidentatus Ledeb. and $S$. mollis Willd., hairs are detected in epidermis along the achene wall while no hairs are identified in other studied species. Prismatic crystals are seen in mid-layer cells in species of $S$. aquaticus Hill ssp. erraticus (Bertol.) V:A. Mathews., S. mollis Willd. and S. trapezuntinus Boiss. whereas no crystals are detected in mid-layer cells of the other species.

Occurrence of secretory ducts and calcium oxalate crystals in the inner parenchyma layer of pericarp were reported in some East Asian representatives of the tribe Cardueae (Asteraceae) (Zarembo and Boyko, 2008).

Genus Senecio was described by Matthews in 5th Volume of Flora of Turkey (1975) and two species were subsequently described in the 11th Volume (annex volume 2) (Kit Tan, 2000). Species Senecio salsuginea and Tephroseris cladobotrys (Synonym: Senecio cladobotrys) were also added to the 
Turkish flora as of 2006 and 2007, respectively (Vural et al., 2006; Budak et al., 2007). All taxa formerly placed in Senecio in Flora of Turkey were then transferred to the genera Senecio and Tephroseris (Hamzaoğlu et al., 2009).

The Tephroseris is represented in Turkish flora by 2 species. The Senecio, according to the latest records, is represented in Turkish flora by 52 taxa (43 species, 3 subspecies and 6 varieties). 21 of these taxa are endemic for Turkey and the rate of endemism is $40 \%$ (Matthews, 1975; Kit Tan, 2000).

The present study seeks to contribute to the resolution of taxonomic problems of genus Senecio based on identification of morphological, anatomical and histological modifications by light microscopy and TEM study of stem and leaf anatomy and seed coat (achene-testa). Derived from the data that set the basis for classification of genus, the subject taxa were reevaluated phylogenetically, doubtful taxonomical validity of some species in Turkey has been clarified and distribution areas and threat categories were updated.

\section{Conclusions}

In all the taxa, leaves are bifacial (dorsiventral) and amphistomatic, stomata are of the anomocytic and amaryllis type. In young stems, stomata are observed in epidermis. In the taxa $S$. maritimus (L.) Rchb., S. sandrasicus P.H.Davis and S. mollis Willd., the stem has intensive cover and glandular hairs.

In the taxa $S$. grandidentatus Ledeb. and $S$. mollis Willd., hairs are observed in the epidermis along the achene wall while no hairs are identified in the epidermises of other species. In the taxa $S$. aquaticus Hill ssp. erraticus (Bertol.) V:A. Mathews., S. mollis Willd. and S. trapezuntinus Boiss., prismatic crystals are seen in mid-layer cells whereas no crystals are detected in mid-layer cells of the other taxa.

\section{Acknowledgement}

We would like to thank the Scientific and Technological Research Council of Turkey (TÜBİTAK, Project No: 107T510) for financial support and the author thank Prof. Dr. Ergin Hamzaoğlu (Primary Education Department, Gazi Education Faculty, Gazi University Ankara) for their help for providing the materials.

\section{References}

1. Algan G, Microtechnique for plant tissues. Firat University Press, Elazığ-Turkey, (1981) Bot. No. 1, p94.

2. Adedeji $\mathrm{O}$ and Jewoola OA. Importance of Leaf Epidermal Characters in the Asteraceae Family. Not Bot Hort Agrobot Cluj 36. 2 (2008): 7-16.

3. Akcin TA and Akcin A. Morphological and anatomical characteristics and taxonomical significance of achene micromorphology of Achillea phrygia and A. gypsicola (Asteraceae) endemic to Turkey. Nordic Journal of Botany 28. (2010): 65-73

4. Akınc1 S and Özhatay E. The Flora of Keltepe Area (Kocaeli/Turkey). Journal of Faculty Pharmacy 37. (2004): 2354 .

5. Akyalcın H, Arabacı T and Yildız B. Pollen morphology of six Achillea L. sec Acbillea (Asteraceae) species in Turkey. Turk J Bot 35. (2011): 183-201.

6. Andre's-Sa'nchez S, Galbany-Casals M, Bergmeier E, Rico E, Martínez-Ortega MM. Systematic significance and evolutionary dynamics of the achene twin hairs in Filago (Asteraceae, Gnaphalieae) and related genera: further evidence of morphological homoplasy. Plant Syst Evol 301. (2015): 1653-1668.

7. Boissier E. Flora Orientalis. 3. (1875): 83-414

8. Bona M. Achene Characteristics of Turkish Centaurea (Asteraceae) and their systematic application. Bangladesh J Bot 43. 2 (2014): 163-168

9. Budak Ü, Hamzaoğlu E and Aksoy A. A New Record for the Flora of Turkey, Tephroseris cladobotrhys (Ledeb.) Griseb. \& Schenk (Senecioneae, Asteraceae). Turk J Bot 31. (2007):265268.

10. Candan F, Uysal T, Tugay O, Bozkurt M, Ertuğrul K and Demirelma H. The examinations of achene ultrastructural features of section Acrolophus (Centaurea, Asteraceae) via scanning electron microscopy. Turk J Bot 40. (2016): 14763

11. Chater AO and Walters SM. Senecio L. In: Tutin T.G., Heywood, V.H., Burges, N.A., Moore D.M., Valentine D.H., Walters S.M., Webb D.A. (eds), Flora Europaea 4. (1976): 191-205. Cambridge Univ Press.

12. de Abreu, VHR, da Conceic a a o Santos J, Esteves RL and Gonc, alves-Esteves V. Pollen morphology of Praxelis (Asteraceae, Eupatorieae, Praxelinae) in Brazil. Plant Syst Evol 301. (2015):599-608.

13. Erik S and Tarkkahya B. On the Flora of Turkey. Kebikeeg. 17. (2004): 139-163.

14. Feinbrun-Dothan N. Senecio L. In: Feinbrun-Dothan N. (eds), Flora Palaestina, The Israel Academy Sciences and Humanities. Jerusalem 3. (1978): 354-7.

15. García Breijo, FJ, Reig Armiñana J, Aguado M, Martinezsanchez JJ, Franco JA and Vicente MJ. Morphology, anatomy and germination response of heteromorphic achenes of Anthemis chrysantha J. Gay (Asteraceae), a critically endangered species. Seed Science Research. 21. 4 (2011):283-294

16. Ghahreman A, Noorbakhsh SN, Mehdigholi K, and Attar F. Pollen Morphology of Artemisia L. (Asteraceae) In Iran. Iran J Bot 13. 1 (2007): 21-29.

17. Hamzaoğlu, E, Budak Ü and Aksoy A. A new taxon of Senecio (Asteraceae) from Karaman (Turkey). Turk J Bot 33. (2009): 285-289.

18. Hoda'lova' I, Mered'a Jr P, Kuc era J, Marhold K, Kempa $\mathrm{M}$, Ols'avska' K, Slova'k M. Origin and systematic position of Jacobaea vulgaris (Asteraceae) octoploids: genetic and morphological evidence. Plant Syst Evol 301. (2015):1517-1541. 
19. Ivashchenko IV and Ivarenko GF. Morphological and anatomical structure of leaves of Artemisia abrotonum (Asteraceae) introduced in Zhytomyr Polissya. Modern Phytomorphology 11. (2017): 35-42.

20. Kandemir A, Makbul S, Türkmen Z and Yllmaz M. Morphological, Anatomical and Palynological Investigation on Sonchus erzincanicus Matthews (Asteraceae) Turk J Bot 30. (2006): 405-411.

21. Karaismailoğlu MC. Morphological and anatomical features of Cypsela of some Crepistaxa (Asteraceae) from Turkey and their taxonomic importance Pak J Bot 47. 4 (2015): 1473-1480

22. Karanovic D, Lukovic J, Zoric L, Anackov G and Boža P. Taxonomic status of Aster, Galatella and Tripolium (Asteraceae) in view of anatomical and micromorphological evidence Nordic Journal of Botany 33. (2015): 484-497.

23. Kit Tan. Senecio L. In: Güner, A, Özhatay, N., Ekim, T., Bașer K.H.C. (eds.), Flora of Turkey and the East Aegean Islands. 11. (2000): 156-157. Edinburgh Univ Press.

24. Luft JH. Improvements in epox yresin embedding methods. J Biophys Biocha Cytol 9. (1961): 409.

25. Matthews VA. Senecio L. Flora of Turkey and the East Aegean Islands, (eds), Davis PH. Edinburgh University Press, Edinburgh 5. (1975): 80-97.

26. Metcalfe CR and Chalk L. Anatomy of dicotyledons 1-2 (1950), Oxford Claredon press.

27. Metcalfe CR and Chalk L. Anatomy of dicotyledons I. (1979) London-Oxford University press London.

28. Nbagwu FN, Chime EG and Unamba CIN. Palynological studies on five species of Asteraceae. African J Biotechn 8. 7 (2009): 1222-1225.

29. Noorbakhsh SN, Ghahreman A and Attar F. Leaf anatomy of Artemisia L. (Asteraceae) in Iran and its taxonomic implications. Iran J Bot. 14.1 (2008): 54-69.

30. Nordenstam B. Senecio L. Iranecio B. Nord. In: Rechinger KH. (eds.) Flora Iranica, Compositae Graz, Austria: Akademische Druck-u. Verlegsanstalt. VII. 164 (1989): 5395.

31. Nordenstam B. Tribe Senecioneae Cass. In: Kubitzki (eds): The families and genera of vascular plants, Flowering Plants. Eudicots, Asterales: Kadereit \& Jeffrey (eds): Heidelberg, Berlin: Springer-Verlag. VIII. (2007): 208-241.

32. Norouzı M, Ghahremanınejad F, Maassoumı AA Safavı SR. Anatomical studies on Scorzonera (Asteraceae) species subgenera Podospermum and pseudopospermum in İan. Modern Phytomorphology 9. (2016): 51-68.

33. Quresh1 SJ, Khan MA, Ahmad M and Arshad M. Morphological, palynological and anatomical investigation of the genus Sonchus L. (Asteraceae) in Pakistan. MES ISSN 1659-3049 3. 1 (2008a): 1-28.
34. Qureshi SJ, Khan MA and Subhan K. Comparatıve morphology, palynology and anatomy of two Asteraceae species. Trakia Journal of Sciences 6.4 (2008b): 52-61.

35. Özbek MU, Mavi İdman DÖ and Bani B. Morphological and anatomical investigation on endemic Cota melanoloma and Cota antitaurica (Asteraceae) in Turkey. Australian Journal of Crop Science AJCS 8. 4 (2014):509-514.

36. Özcan M, Demiralay M and Kahraman A. Leaf anatomical notes on Cirsium Miller (Asteraceae, Carduoideae) from Turkey. Plant Syst Evol 301. (2015):1995-2012.

37. Özmen E, Kızılpınar İ, Özudoğru B, Doğan C and Erik S. Pollen morphology of some taxa of aromatic genus Tanacetum L. (Asteraceae). FABAD J Pharm Sci 34. (2009): $1-11$.

38. Ruvimbo JM and Glynis VC. A phenetic study of the Emilia coccinea complex (Asteraceae, Senecioneae) in Africa. Plant Syst Evol 302. (2016):703-720.

39. Sato JE. A modified method for bad staining of thin sections, J Electron Microscopy 16. (1967): 133.

40. Selvi S, Paksoy MY, Polat R and Cakilcioğlu U. Micromorphological and Anatomical Characteristics of the Genus Chrysophthalmum Schultz Bip. (Asteraceae) Growing in Turkey Proc Natl Acad Sci India Sect B Biol Sci 84. 2 (2014):431-438

41. Shishkın BK. Senecio L. In: Shishkin, BK. Bobrov EG. (eds), Flora of the U.S.S.R. Dehra Dun, Bishen Singh Mahedra Pal Singh and Koeltz Scientific Books. 26. (1995): 801-908.

42. Sosa MM, Gisela M, Pico V and Dematteis M. Comparative anatomy of leaves and stems in some species of the South American genus Chrysolaena (Vernonieae, Asteraceae) and taxonomic implications Nordic Journal of Botany 32. (2014): 611-619.

43. Stempak, J.G, R.T. Ward. An improved staining method for electron microscopy. J. Cell Biol. 22 (1964): 697.

44. Türkmen Z, Makbul S, Coșkuncelebi K and Beyazoğlu O. Palynological observations on the genus Scorzonera L. (Asteraceae) from north-east Anatolia (Turkey) Turk J Bot 34. (2010): 495-512.

45. Zarembo EV and Boyko EV. Carpology of some East Asian Cardueae (Asteraceae). Anales del Jardín Botánico de Madrid. 65. 1 (2008): 129-134.46.

46. Vural M, Duman H, Aytaç Z and Adigüzel N. Saponaria karapinarensis, Senecio salsuginea and Centaurea turgoluensis Three New Species from Central Anatolia Turkey, Belgium Journal of Botany. 139. 2 (2006): 252-260.

\section{Cite this article as:}

Büyükkartal Hatice Nurhan, Hatice Çölgeçen, Ümit Budak. Stem and leaf anatomy and achene structure in some species of Senecio (Asteraceae). Annals of Plant Sciences 6.12 (2017) pp. 1845-1854.

doi: http://dx.doi.org/10.21746/aps.2017.6.12.7 